\title{
EN 338 STRENGTH GRADE AND UNCERTAINTY MODELS OF MATERIAL PROPERTIES FOR NIGERIAN GROWN TERMINALIA SUPERBA (WHITE AFARA) TIMBER SPECIE
}

\author{
J. M. Kaura ${ }^{1}$, I. Abubakar ${ }^{2}$, I. Aliyu ${ }^{3}$ and U. Hassan ${ }^{4}$ \\ 1,2,3 Department of Civil EngineERING, AHMADU BelLo University, ZARIA. NIGERIA \\ 4 DANTATA AND SAWOE NigERIA LIMITED, KaNO. NIGERIA \\ E-mail addresses:1 jmkaura@abu.edu.ng,2idrcivil1@gmail.com,3ibrahimaliyu67@yahoo.com, \\ 4 hassanmmd@yahoo.com
}

\begin{abstract}
In this paper, the EN 338 strength class of Nigerian grown Terminalia superba timber specie was determined. This will enable the utilisation of the specie in the design of timber structures using Eurocode 5. The uncertainty models (mean, coefficients of variation and theoretical distribution models) of the tested specie were also generated. This information is required if structural reliability analysis and design is to be undertaken. The strength classification and the material properties were based on detailed laboratory experiment conducted on samples of the tested timber specie based on EN 408 (2004) and EN 13153-1 (2002). The laboratory data was analysed using an open source statistical computer package, Easyfit (2010) in accordance with EN 384 (2004). Terminalia superba was found to be of strength class D24 according to EN 338 (2009). The statistical analysis revealed that the coefficient of variation of modulus of elasticity is $21 \%$. The coefficient of variations of both the bending strength and density is $19 \%$. It was also found that, the best theoretical distribution models for density is normal distribution, while lognormal distribution was found to be the best distribution model for both bending strength and modulus of elasticity. Due to the high coefficients of variation of material properties of timber as indicated in this study, it is recommended that EN 338 strength class should include the information on the statistical parameters of timber. With this, the design criteria of timber structures using Eurocode 5 can be enhanced by the use of structural reliability method in order to fully accommodate uncertainties.
\end{abstract}

Keywords: Bending strength, Coefficient of variation, Density, Modulus of Elasticity, Strength class, Terminalia superba, Uncertainty

\section{INTRODUCTION}

NCP 2 [14] is the Nigerian structural timber design code for Nigeria. This code is based on permissible stress design method, developed based on [4]. With the introduction of another permissible stress design code; BS 5268 [1] in 1984, CP 112 [4] was withdrawn. BS 5268 was further revised in 2002. Eight years later, on $1^{\text {st }}$ April, 2010[1], was withdrawn and replaced with the Eurocode 5, which is a limit state design code. Nigeria desires to be among the first twenty great economies by the year 2020 (vision 20/2020). There is the need to change form the use of permissible stress design method to the modern limit state design method. The most economical option is to adopt the
Eurocodes, as done in many commonwealth countries, such as South Africa.

In spite of the series of revision in the timber design standards in Britain, as well as the shift from the permissible stress to the limit state design method, the NCP 2 [14] was never updated, from the time it was first developed. In comparison to other building materials such as steel and concrete, the properties of timber materials are not designed or produced by means of some recipe but may be ensured to fulfil given requirements only by quality control procedures known as grading. Grading refers to the classification of timber species of similar material properties into the same group. 
The resistance models in the Eurocode 5 require that solid timber be graded based on EN 338 [8] specification. EN 338 classified timber into groups based on their reference material properties (density, bending modulus of elasticity and bending strength) that are obtained from laboratory experiments according to EN 408 [7] and EN 384 [6]. Generally, strength grading of timber offer a number of advantages both to the designer and the supplier of timber. The designer can undertake his design without the need to check on the availability and price of a large number of species and grades which he might use. Suppliers can supply any of the species/grade combinations that meet the strength class in a specification. The concept also allows new species to be introduced onto the market without affecting existing specifications for timber. In summary, the allocation of specie to a strength class allows engineers to use the mechanical properties of the strength class in limit state design of timber structures.

There are a total of 18 strength classes, C14 to C40 for softwoods and D18 to D70 for hardwoods [8]. The number in each strength class refers to its 'characteristic bending strength' value. In this paper, the strength grade forTerminalia superba was determined. This timber specie gained wide acceptance by Nigerian construction industry, especially for roof truss construction. The strength class of Terminalia superba according to NCP 2 [14] is N6. The grading in NCP 2 is based on grade stresses, that contained an unknown factor of safety. In Eurocode 5 [5], the strength properties are separated from factors of safety.

Terminalia superba is a large tree, up to $50 \mathrm{~m}$ tall and $5 \mathrm{~m}$ in girth. It is essentially a tree of deciduous forest (Hardwoods). It is a native of Congo, Cameroon, Angola, Benin, Central Africa republic, Cote d'voire, Democratic Republic of Congo, Equatorial Guinea, Gabon, Ghana, guinea, Liberia, Sierra Leone, and Nigeria [3]. It is light yellow in colour.

\section{MATERIALS AND METHODS}

Timber samples of Terminalia superba (White Afara) obtained from Kaduna and Zaria timber sheds were subjected to test in the heavy duty structural engineering laboratories of the Department of Civil Engineering, Ahmadu Bello University, Zaria, Nigeria. One of the objectives of the testing programme was to allocate the timber specie to appropriate strength classes, and generate uncertainty models of material properties, that may be useful for structural reliability analysis of timber structures designed with the specie. The possible strength classes are those contained in EN 338 [8].

\subsection{Materials}

The number and choice of required tests were determined by the requirements of EN 384 [6]. The programme of tests was designed to determine the reference material properties (bending strength, bending modulus of elasticity and density) as well as the moisture content of the species under investigation. Four point bending tests were conducted in accordance with EN 408 [7]. Forty sample were used for each test as prescribed in EN 384 [6]. The forty samples were made of four sets of ten sub-samples. Each of the subsample was obtained randomly from a different supplier, based on the assumption that, the samples were independent.

The test specimens were first subjected to protected exterior drying for one months, for the samples to attain equilibrium moisture content environmentally. The samples were then exposed to laboratory condition. Conditioning requirement is that, prior to testing, specimens must be conditioned to $(20 \pm 2){ }^{\circ} \mathrm{C}$ and (65 \pm 5$) \%$ relative humidity [6].

There were two groups of test samples; test beams for bending test, and small sections for density and moisture content test. Each of the bending test beams was nominally $50 \mathrm{~mm}$ wide and $75 \mathrm{~mm}$ depth, and 1500 mm long.

\subsection{Density and Moisture Content Test Methods}

The density and moisture content tests were in accordance with EN 13153-1 [9], The specimens were first weighed on a high precision electronic weighing balance with accuracy of $0.01 \%$, to obtain the initial bulk weight of each piece. The specimens were then kept in an electric oven at $105^{\circ} \mathrm{C}$ for 24 hours. They were weighed again to obtain the oven dried weight. The density values for the samples were obtained using equation 1.0 and 2.0, while the moisture contents were obtained using equation. 3.0,

$$
\begin{aligned}
& \text { Wet density: } \rho_{b}=\frac{m_{b}}{V} \\
& \text { Dry density: } \rho_{d}=\frac{m_{0}}{V} \\
& \text { Moisture content }(\%)=\frac{m_{b}-m_{0}}{m_{0}} \times 100
\end{aligned}
$$

In (1), (2) and (3) $\mathrm{m}_{\mathrm{b}}$ is the bulk mass in $\mathrm{kg} ; \mathrm{M}_{0}$ is the oven dry mass in $\mathrm{kg} ; \mathrm{V}$ is the volume in $\mathrm{m}^{3} ; \rho_{\mathrm{b}}$ is the 
bulk density in $\mathrm{kg} / \mathrm{m}^{3}$ and $\rho_{\mathrm{d}}$ is the dry density in $\mathrm{kg} / \mathrm{m}^{3}$.

\subsection{The Bending Test Method}

The determination of global modulus of elasticity of timber using four-point bending test according to EN 408 [7] is based on the application of loading at the central third of the test piece. Global rather than local modulus of Elasticity was adopted in this research because the later do not give consistent and reliable results [2], as its determination is based on measurement of a deflection over a relatively short span between the loading point. The deflections are small, often less than $1 \mathrm{~mm}$. Hence the method is sensitive to measurement errors. Such errors can be caused by twisting of the timber during the test [2]. The four point bending test setup is in Figure 1.

The modulus of elasticity is obtained by considering bending deflection of the entire span of the timber test specimen relative to the end supports as specified in EN 408 [7]. The modulus of elasticity and the bending strength were obtained from equations 4.0 and 5.0 respectively as follows:

$$
\begin{aligned}
& \mathrm{E}_{\mathrm{m}}=\frac{\mathrm{L}^{3}\left(\mathrm{~F}_{2}-\mathrm{F}_{1}\right)}{4.7 \mathrm{bh}^{3}\left(\mathrm{w}_{2}-\mathrm{w}_{1}\right)} \\
& \mathrm{f}_{\mathrm{m}}=\frac{\mathrm{a} \mathrm{F}_{\max }}{2 \mathrm{~W}}
\end{aligned}
$$

where $\left(F_{2}-F_{1}\right)$ is the load increment between two load intervals $\mathrm{F}_{1}$ and $\mathrm{F}_{2}$ in $\mathrm{N}$. $\left(\mathrm{w}_{2}-\mathrm{w}_{1}\right)$ is the corresponding deflection increment. $\mathrm{L}, \mathrm{b}, \mathrm{h}$, are beam span, beam width and beam depth, all in $\mathrm{mm}$. $\mathrm{F}_{\max }$ is the load at point of failure of the beam in N. a is the distance between one load and the nearest support in $\mathrm{mm}$. $\mathrm{W}$ is the section modulus of the beam in $\mathrm{mm}^{3}$.

\section{$2.412 \%$ moisture content adjusted material properties}

It is well documented that most properties of timber vary with variation in moisture content below fibre saturation point [15]. Following EN 384 [6], Strength class values are derived from timber at about $12 \%$ moisture content, which is taken as a reference moisture content. Therefore, adjustments to results are desirable. Bending strength and modulus of elasticity values are adjusted to $12 \%$ reference moisture content using equations (6)and (7) [2], [13], while for density values are adjusted to, the $12 \%$ reference moisture content based equation 8.0

$$
\begin{aligned}
& \mathrm{f}_{\mathrm{m}, 12 \%}=\frac{\mathrm{f}_{\text {measured }}}{1+0.0295(12-\mathrm{u})} \\
& \mathrm{E}_{\mathrm{m}, 12}=\frac{\mathrm{E}_{\text {measured }}}{1+0.0143(12-\mathrm{u})} \\
& \rho_{12}=\rho_{\text {measure }}\left[1-\frac{\mathrm{u}-12}{200}\right]
\end{aligned}
$$

were $\mathrm{f}_{\mathrm{m}, 12 \%}, \mathrm{E}_{\mathrm{m}, 12}$ and $\rho_{12}$ are the bending strength, modulus of elasticity and density, all at $12 \%$ moisture content. $\mathrm{f}_{\text {measured }}, \mathrm{E}_{\text {measure }}$ and $\rho_{\text {measure }}$ are the measured bending strength, measured modulus of elasticity and measured density corresponding to the samples actual equilibrium moisture content obtained from the laboratory, $\mathrm{u}$ is the measured moisture content of the timber specimen.

\subsection{Investigation of the equality of mean values of the material properties}

Four sets of independent samples of the tested timber specie were used for the bending, moisture content and the density tests. To be able to use the generated material properties, there was the need to carry out statistical test with the view to ascertain the homogeneity of the samples. There was variability on material properties between and within samples need to be investigated. Two-way Analysis of variance (ANOVA) was adopted for the exercise. Analysis of variance is a statistical technique whereby total variance in a set of data is partitioned into several components. Associated with each of these components is a specific source of variation, so that in the analysis, it is possible to ascertain the magnitude of the contribution of each of these sources to the total variation.

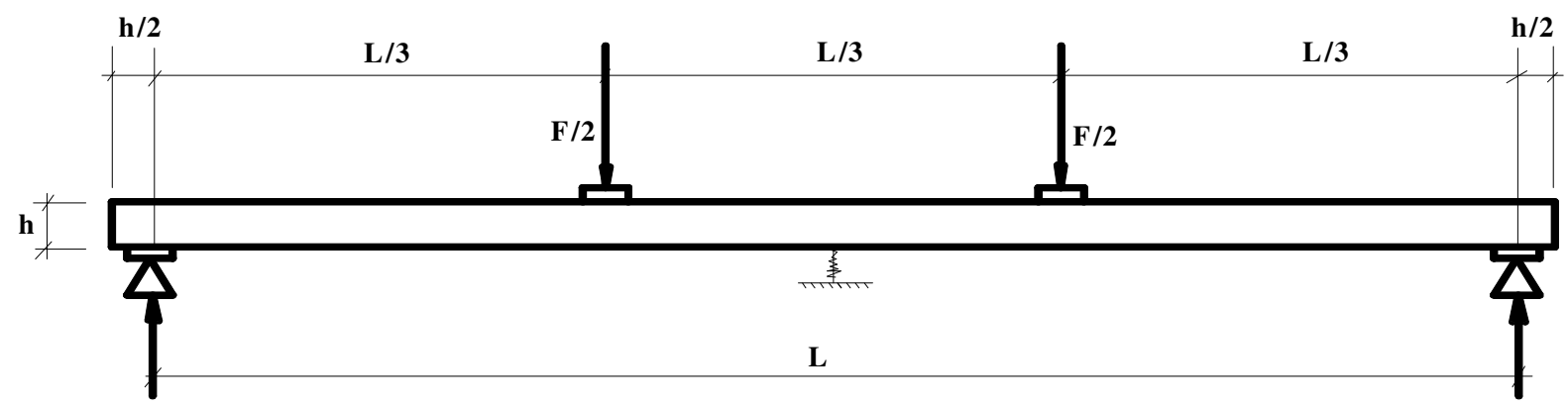

Figure 1. Four-point bending test set-up [7] 


\subsection{Uncertainty Models of the Material Properties}

As a result of grading, timber is provided to the market as a graded material. The grades imply that the material properties lie within desirable and predictable limits. However, the material properties of timber grades have to be considered as random variables and the properties of timber grades are characterised (and communicated) through specific fractile values of the assumed probability distribution functions of the material properties of interest [12]. In addition, uncertainty models of the material properties are required for the determination of probability of failure of timber structures [10,17]. These models include mean values, coefficients of variation and theoretical distribution. The characteristic values and the uncertainty models were established in this study, by analysing the laboratory test results for the reference material properties (density, modulus of elasticity and bending strength) using an open source Microsoft Excel based statistical computer package; Easyfit. In the development of the appropriate distribution models for the material properties three distribution modes, namely normal, lognormal and gumbel distribution were fitted to the laboratory test data using Kolmogorov smirnov test. The uncertainty models for the other material properties (tension strength parallel and perpendicular to grain, compression strength parallel and perpendicular to grain, shear strength and shear modulus), known as derived material properties are derived from the reference properties using empirical models given in EN 384 [6] and JCSS [11].

\subsection{Allocation of Strength Classes}

Strength classes are sets of material properties that can be assigned to specific combinations of timber species and strength grades. The use of strength classes is intended to simplify the specification of timber, since it groups species in pre-defined categories. Characteristic values are taken from bending strength, bending modulus of elasticity and density. The allocation to a strength class is governed by the lowest strength class applicable to one of these properties. The classification of the species into various strength classes was made using the characteristic bending strength, mean value of density and mean values of modulus of elasticity. Terminalia superba is Hardwood specie [3], [4]. The limiting values of the reference material properties for hardwoods from EN 338 [8] are presented in Table 1.0.

\section{RESULTS AND DISCUSSION}

\subsection{Material properties}

The moisture content, and the reference material properties (density, modulus of elasticity and bending strength) were generated statistically by analysing the test data using Easyfit, based on EN 384 [6]. The generated material properties were adjusted to $12 \%$ reference moisture contents using equations 6.0 to 8.0. The results are presented in Table 2.

It can be observed from the table that, the tested specie has a mean moisture content of $20.96 \%$, which is almost $43 \%$ higher than the reference moisture content of $12 \%$.

Table 1: Limiting Values for EN 338 Classification into Hardwood Classes

\begin{tabular}{ccccc}
\hline S/No. & $\begin{array}{c}\text { Strength } \\
\text { Class }\end{array}$ & $\begin{array}{c}\text { Limits of Characteristic Bending } \\
\text { Strength }\left(\mathrm{N} / \mathrm{mm}^{2}\right)\end{array}$ & $\begin{array}{c}\text { Limits of Characteristic } \\
\text { Density }\left(\mathrm{kg} / \mathrm{m}^{3}\right)\end{array}$ & $\begin{array}{c}\text { Limits of Mean Bending } \\
\text { Strength }\left(\mathrm{N} / \mathrm{mm}^{2}\right)\end{array}$ \\
\hline 1 & D18 & $\mathrm{f}_{\mathrm{m}, \mathrm{k}} \leq 18$ & $\rho_{\mathrm{k}} \leq 475$ & $\mathrm{E}_{\text {mean }} \leq 9.5$ \\
2 & D24 & $18<\mathrm{f}_{\mathrm{m}, \mathrm{k}} \leq 24$ & $475<\rho_{\mathrm{k}} \leq 485$ & $9.5<\mathrm{E}_{\text {mean }} \leq 10$ \\
3 & D30 & $24<\mathrm{f}_{\mathrm{m}, \mathrm{k}} \leq 30$ & $485<\rho_{\mathrm{k}} \leq 640$ & $9.5<\mathrm{E}_{\text {mean }} \leq 10$ \\
4 & D35 & $30<\mathrm{f}_{\mathrm{m}, \mathrm{k}} \leq 35$ & $640<\rho_{\mathrm{k}} \leq 670$ & $9.5<\mathrm{E}_{\text {mean }} \leq 10$ \\
5 & D40 & $35<\mathrm{f}_{\mathrm{m}, \mathrm{k}} \leq 40$ & $670<\rho_{\mathrm{k}} \leq 700$ & $10<\mathrm{E}_{\text {mean }} \leq 11$ \\
6 & D50 & $40<\mathrm{f}_{\mathrm{m}, \mathrm{k}} \leq 50$ & $700<\rho_{\mathrm{k}} \leq 780$ & $11<\mathrm{E}_{\text {mean }} \leq 14$ \\
7 & D60 & $50<\mathrm{f}_{\mathrm{m}, \mathrm{k}} \leq 60$ & $780<\rho_{\mathrm{k}} \leq 840$ & $14<\mathrm{E}_{\text {mean }} \leq 17$ \\
8 & D70 & $70 \leq \mathrm{f}_{\mathrm{m}, \mathrm{k}}$ & $1080 \leq \rho_{\mathrm{k}}$ & $20 \leq \mathrm{E}_{\text {mean }}$ \\
\hline
\end{tabular}

(Source: EN 338, [8])

Table 2: Statistical parameters for the reference material properties and moisture content

\begin{tabular}{llll}
\hline Material Property & Mean & $\begin{array}{l}\text { Standard } \\
\text { Deviation }\end{array}$ & Coefficient of Variation \\
\hline Moisture Content $(\%)$ & 20.96 & 4.81 & 0.23 \\
Density $\rho_{12}\left(\mathrm{~kg} / \mathrm{m}^{3}\right)$ & 533.89 & 103.73 & 0.19 \\
Modulus of elasticity $\mathrm{E}_{\mathrm{m}, 12}\left(\mathrm{~N} / \mathrm{mm}^{2}\right)$ & 11614.0 & 2449.2 & 0.21 \\
Bending strength $\mathrm{f}_{\mathrm{m}, 12}\left(\mathrm{~N} / \mathrm{mm}^{2}\right)$ & 83.63 & 15.73 & 0.19 \\
\hline
\end{tabular}


This therefore justified the adjustment of the values of the reference material properties to agree with material property limit given in EN 338 [8].For the reference material properties, the modulus of elasticity shows highest coefficient of variation of $21 \%$. Both density and bending strength have $19 \%$ coefficient of variation. Results indicated that the material properties of solid timber have high coefficients of variation. They are therefore highly uncertain. This therefore calls for the accommodation of probabilistic technique in the design of timber structures, in order to fully accommodate the inherent uncertainties.

Table 3 presents the results of two-way analysis of variance (ANOVA), implemented on "Analyse it" statistical package. The results shows that, the assumption of equal mean density, modulus of elasticity and bending strength within samples of species can be accepted. However, the null hypothesis for equality of mean value of material properties between timber species is not valid, and therefore rejected. The conclusion is that, the samples of Terminalia superba considered for test were not affected by the difference in their sources. The test result can therefore be used to classify the specie into its appropriate strength class in accordance with EN 338 [8].

The statistical parameters of the reference material properties of the Terminalia superba are presented in Table 4.0. These values were derived from the reference material properties using standard property relationship given in EN 384 [6] and JCSS [11].

The results of Kolmogorov Smirnov are presented in Table 5.0. The aim of the test was to identify the appropriate theoretical distribution models for each of the reference material properties. The critical value for Kolmogorov Smirnov test at 5\% level of significance, for density for all the Terminalia is 0.2101 . This value is greater than the K-S statistics of all the three fitted distribution models (normal, lognormal and gumbel distribution). The hypothesis that the density values belong to each of the three tested distribution models is now accepted. This implied that, all the three distribution models can be used to model the density of each of the specie. However, considering the preferential ranking of the three fitted distribution model, it can be concluded that, the density of each of the species can best be modelled using Normal distribution, which was ranked as 1 .

Similarly, for the modulus of elasticity the critical value at $5 \%$ level of significance is greater than the corresponding K-S statistics of the considered distribution models (normal, lognormal and gumbel distribution). Therefore, each of the distribution models can be used to model the modulus of elasticity of timber. Likewise, considering the ranking of the validity of the three distribution model, it is observed that, the most fitted distribution model with rank 1 , for the modulus of elasticity Terminal superba is lognormal distribution.

For the bending strength also, the critical value at 5\% level of significance is greater than the corresponding $\mathrm{K}$-S statistics of the normal, lognormal, and gumbel distribution. Therefore each of the three distribution models can be used to model the bending strength of the specie. Lognormal distribution has the highest rank of 1 . It is therefore the best fit for bending strength.

Table 3: Two-way ANOVA (Density)

\begin{tabular}{llllll}
\hline Material Property & \multicolumn{1}{c}{ Source of variability } & F-Statistics & p-value & Critical value & Decision \\
\hline \multirow{2}{*}{ Density } & Within timber specie & 1.11 & 0.3244 & 0.05 & Reject \\
& Between timber species & 566.03 & 0.0001 & 0.05 & Accept \\
\hline Modulus of & Within timber specie & 1.10 & 0.3330 & 0.05 & Reject \\
Elasticity & Between timber species & 357.58 & 0.0001 & 0.05 & Accept \\
\hline Bending & Within timber specie & 1.00 & 0.4768 & 0.05 & Reject \\
Strength & Between timber species & 125.03 & 0.0001 & 0.05 & Accept \\
\hline
\end{tabular}

Table 4: Statistical Parameters of the derived material properties

\begin{tabular}{llcc}
\hline Derived Material Property & Mean $\left(\mathrm{N} / \mathrm{mm}^{2}\right)$ & Coefficient of Variation $(\%)$ & $\begin{array}{c}\text { Characteristic } \\
\text { Values }\left(\mathrm{N} / \mathrm{mm}^{2}\right)\end{array}$ \\
\hline Tension Strength Parallel to Grain & 55.19 & 0.23 & 34.25 \\
Tension Strength Perpendicular to Grain & 0.90 & 0.19 & 0.62 \\
Compression Strength Parallel to Grain & 45.90 & 0.15 & 34.54 \\
Compression Strength Perpendicular to Grain & 4.22 & 0.19 & 2.90 \\
Shear Strength & 7.82 & 0.19 & 5.37 \\
Shear Modulus & 751.65 & 0.21 & 491.20 \\
\hline
\end{tabular}


Table 5:Kolmogrov Smirnov Goodness of Fit Tests on Modulus of Elasticity Test Results At 5\% Level of Significance $\left(\alpha_{0.05}\right)$

\begin{tabular}{|c|c|c|c|c|c|}
\hline Material Property & Distribution & Statistics & P-value & Rank & $\begin{array}{l}\text { Reject } \\
\text { Hypothesis }\end{array}$ \\
\hline \multirow{3}{*}{ Density } & Normal & 0.0599 & 0.9948 & 1 & No \\
\hline & Lognormal & 0.0870 & 0.9118 & 2 & No \\
\hline & Gumbel & 0.1178 & 0.7266 & 3 & No \\
\hline \multirow{3}{*}{$\begin{array}{l}\text { Modulus of } \\
\text { Elasticity }\end{array}$} & Normal & 0.0761 & 0.7040 & 1 & No \\
\hline & Lognormal & 0.1076 & 0.7462 & 2 & No \\
\hline & Gumbel & 0.1214 & 0.5150 & 3 & No \\
\hline \multirow{3}{*}{$\begin{array}{l}\text { Bending } \\
\text { Strength }\end{array}$} & Normal & 0.1075 & 0.9612 & 2 & No \\
\hline & Lognormal & 0.1035 & 0.7027 & 1 & No \\
\hline & Gumbel & 0.1254 & 0.5562 & 3 & No \\
\hline
\end{tabular}

Table 6: Proposed Allocations of Strength Class for Terminalia superba

\begin{tabular}{|c|c|c|c|c|c|}
\hline $\begin{array}{c}\text { Reference Material } \\
\text { Properties }\end{array}$ & $\begin{array}{l}\text { EN } 338 \\
\text { (D24) }\end{array}$ & $\begin{array}{l}\text { 12\% Adjusted } \\
\text { Values }\end{array}$ & $\begin{array}{c}\text { NCP } 2 \text { Dry Basic } \\
\text { Stress (18\% } \\
\text { MC) }\end{array}$ & $\begin{array}{l}\text { NCP } 2 \\
\text { Strength } \\
\text { Class }\end{array}$ & $\begin{array}{c}\text { Allocated } \\
\text { Strength Class } \\
(\text { EN 338, 2009) }\end{array}$ \\
\hline $\begin{array}{l}\text { Bending Strength } \\
\left(\mathrm{N} / \mathrm{mm}^{2}\right)\end{array}$ & $\begin{array}{c}24 \\
\text { (Characteristic }\end{array}$ & $\begin{array}{c}68.67 \\
\text { (Characteristic) }\end{array}$ & $\begin{array}{c}11.2 \\
\text { (factored) }\end{array}$ & & \\
\hline Density $\left(\mathrm{kg} / \mathrm{m}^{3}\right)$ & $\begin{array}{c}475.0 \\
(\text { mean })\end{array}$ & $\begin{array}{l}509.97 \\
\text { (mean) }\end{array}$ & $\begin{array}{c}464.0 \\
\text { (factored) }\end{array}$ & N6 & D24 \\
\hline $\begin{array}{l}\text { Modulus of Elasticity } \\
\left(\mathrm{kN} / \mathrm{mm}^{2}\right)\end{array}$ & $\begin{array}{c}10.0 \\
\text { (mean) }\end{array}$ & $\begin{array}{c}13.32 \\
\text { (mean) }\end{array}$ & $\begin{array}{c}7.10 \\
\text { (factored) }\end{array}$ & & \\
\hline
\end{tabular}

\subsection{Allocation of Strength Class}

The Nigerian grown Terminalia superba timber specie was graded in accordance with class limits for hardwood timber species of EN 338 [8]. A timber specie can be assigned to a particular strength class if the characteristic value of its bending strength, the mean values of its density and modulus of elasticity are equal to or lower than the corresponding values for that class in EN 338 [9]. From the result obtained in this study, the characteristic bending strength for the Terminalia superba adjusted to $12 \%$ reference moisture content is $68.67 \mathrm{~N} / \mathrm{mm}^{2}$. The mean value of its modulus of elasticity at $12 \%$ reference moisture content is $13320 \mathrm{~N} / \mathrm{mm}^{2}$, and the mean value of its density at $12 \%$ reference moisture content is 509.97 $\mathrm{kg} / \mathrm{m}^{3}$. The class limit where all the three reference material properties fall in the strength class D24. The summary of the strength classification is presented in Table 6.0. The material properties of the EN 338 [8] assigned strength class was compared with the properties of the NCP 2 [14] strength grade of N6 for the Terminalia superba.

\section{CONCLUSION}

Reference material properties of Nigerian grown Terminalia timber specie were generated from laboratory tests according EN 408 [7] and analysed based on EN 304 [6] using Easyfit statistical package. The statistical analysis revealed that the coefficient of variation of modulus of elasticity is $21 \%$. The coefficients of variations of both the bending strength and density are $19 \%$. It was also found that, the best theoretical distribution models for density is normal distribution, while lognormal distribution was found to be the best distribution model for both bending strength and modulus of elasticity. The timber specie was classified as D24 according to EN 338 [8].

Due to the high coefficients of variation of material properties of timber as indicated in this study, it is recommended that EN 338 [8] strength class should include the information on the statistical parameters of timber. With this, the design criteria of timber structures using Eurocode 5 can be enhanced by the use of structural reliability method in order to fully accommodate uncertainties.

\section{REFERENCES}

[1] BS 5268-2: 2002. Structural Use of Timber, Part 2, Code of Practice for Permissible Stress Design, Materials and Workmanship, British Standard Institute (BSI), 2007.http://davidmuir.com/ offshore/ODB/Timber Codes/BS\%205268\%20part \%202.pdf. Accessed February, 2nd, 2013.

[2] Bostrom. L. (1994), Machine Strength Grading, Comparison of For Different Systems.Swedish National Testing and Research Institute for Building Technology sp. Technical Report, Sweden, 1994, pp 49-57. 
[3] CIRAD, Tropix-African Wood. "Production and Processing of Tropical Wood" Research Unit Centre de coopération internationaleen rechercheagronomique pour le développement, Forestry Department. http://tropix.cirad.fr Lafrica/africa.html. Accessed, August 25th 2009.

[4] CP 112: Part 2: 1971, British Standard Code of Practice for the Structural use of Timber. The Council for Codes and Practice, British Standard Institute, London.http://davidmuir.com

Loffshore/ODB/Timber Codes/cp112.pdf Accessed June, 23, 2010.

[5] Eurocode 5, part 1-1. Eurocode 5: Design of Timber Structures-part 1-1: General Common Rules for Buildings, CSI, Prague, December, 2004.

[6] EN 384. Timber Structures; Structural timber Determination of Characteristic Values of Mechanical Properties and Density. 2004, ComitéEuropéen de Normalisation, Brussels, Belgium.

[7] EN 408. European Standard: Timber structures Structural Timber - Determination of some physical and mechanical properties. 2004, ComitéEuropéen de Normalisation, Brussels, Belgium.
[8] EN 338, Structural timber - Strength Classes. European Committee for Standardization. Austrian Standards Institute Heinestraße 38, 1020 Wien, 2009.

[9] EN 13153-1: 2002. Moisture Content of a Piece of Sawn Timber-Part 1.Determination by Oven Dry Method.ComitéEuropéen de Normalisation, Brussels, Belgium, 2002.

[10] Aguwa, J. I. "Structural Reliability of the Nigerian Grown Abura Timber Bridge Beam Subjected to Bending and Deflection Forces", Nigerian Journal of Technology, Vol 32, Number 2, 2013, pp 241-252.

[11] Heikkila, K. and Herajarvi, H. "Stiffness and Strength of $45 \times 95 \mathrm{~mm}$ beams Glued from Norway Spruce Using 8 Different Structural Models". Conference COST E53, Delft, the Netherlands, October, 29-30, 2008, pp 271-280.

[12] JCSS "Joint Committee on Structural Safety: Probabilistic Model Code: Material Properties of Timber", 2006. . http://www.jcss.ethz.ch.Accessed on $3^{\text {rd }}$ February, 2013. 